\title{
Aktivitas Antifungi Ekstrak Daun Teh Terhadap PertumbuhanAspergillus flavus
}

\author{
Putriana Indah Lestari \\ Rumah Sakit Penyakit Infeksi Prof. Dr. Sulianti Saroso
}

\begin{abstract}
Abstrak.Aspergillus flavus merupakan jamur patogen penghasil racun aflatoksin yang banyak mengontaminasi komoditi hasil pertanian dan bahan pangan. Penelitian ini bertujuan untuk mengetahui aktivitas antifungi ekstrak daun teh terhadap pertumbuhan $A$. flavus dan konsentrasi ekstrak daun teh yang efektif dalam menghambat pertumbuhan $A$. flavus. Perlakuan yang dicobakan terdiri atas 7 konsentrasi ekstrak daun teh yang yaitu 0 (kontrol); 0,$5 ; 1,0 ; 1,5 ; 2,0 ; 2,5 ; 3,0$ dan $3,5 \mathrm{mg} / \mathrm{ml}$. Variabel bebas berupa konsentrasi ekstrak daun teh dan variabel tergantung berupa persentase penghambatan ekstrak daun teh terhadap $A$. flavus. Parameter yang diamati adalah diameter pertumbuhan $A$. flavus, $\mathrm{pH}$ media dan suhu ruang. Data dianalisis dengan menggunakan Analisis Ragam (uji F) pada tingkat kepercayaan 95 dan 99\%, jika berpengaruh nyata dilanjutkan dengan uji Beda Nyata Jujur (BNJ) 5\%. Hasil penelitian menunjukkan bahwa ekstrak daun teh mampu menghambat pertumbuhan $A$. flavus dan konsentrasi $2,5 \mathrm{mg} / \mathrm{ml}$ merupakan konsentrasi efektif menghambat pertumbuhan $A$. flavus. Kandungan metabolit sekunder daun teh yang dapat dideteksi yaitu golongan alkaloid, flavonoid, terpenoid, tanin dan asam lemak.
\end{abstract}

Kata kunci : Aktivitas antifungi, Ekstrak daun teh, Konsentrasi, Aspergillus flavus

Korespondensi :Putriana Indah Lestari, Direktorat Pengkajian PI \& PM, RSPI Prof. Dr. Sulianti Saroso, Jl. Baru Sunter Permai, Papanggo, Tanjung Priok, Jakarta Utara

Telp : (021) 6506559 ext.5001

Email : arsiputri@gmail.com

\section{PENDAHULUAN}

Aspergillus flavus merupakan salah satu jamur mikroskopis patogen yang menghasilkan metabolit sekunder berupa racun (mikotoksin) yang disebut dengan aflatoksin. Aflatoksin banyak mengontaminasi berbagai jenis komoditas pertanian seperti kacang-kacangan, jagung dan beras. Hasil pertanian yang terkontaminasi aflatoksin dengan kadar yang melebihi batas yang telah ditetapkan dapat membahayakan ternak jika tanaman tersebut dijadikan sebagai pakan. Ternak yang memakan pakan ternak yang telah terkontaminasi aflatoksin dapat mengalami penurunan berat badan, peningkatan berat limfa dan ginjal serta terjadinya atropi pada hati ${ }^{1}$. Sisa aflatoksin juga akan terdapat pada beberapa produk ternak seperti telur, daging dan hati ${ }^{2}$. Produk ternak tersebut dapat membahayakan kesehatan apabila dikonsumsi oleh manusia. Bahaya aflaktosin bagi manusia telah dilaporkan oleh Pitt dan Hocking pada tahun $1997^{3}$. Hasil penelitian menunjukkan bahwa aflatoksin menyebabkan kerusakan hati akut, sirosis hati, induksi tumor dan efek teratogenik. Hasil penelitian tersebut didukung oleh pernyataan Purwijantiningsih et al. bahwa aflatoksin pada manusia erat kaitannya dengan hepatotoksisitas ${ }^{4}$.

Berdasarkan kerugian dan bahaya yang disebabkan oleh aflatoksin maka perlu dilakukan suatu upaya penanggulangan yang efektif. Upaya yang telah dilakuka para petani untuk menekan kerugian akibat kontaminasi aflatoksin yaitu dengan cara mengendalikan $A$. flavus. Para petani mencuci hasil panen menggunakan air garam $1-2,5 \%$, namun upaya tersebut belum berhasil karena hanya mampu menekan kerusakan tidak lebih dari $5 \%{ }^{5}$. Berdasarkan hal tersebut, beberapa peneliti berusaha mencari solusi yang lebih efektif yaitu dengan cara fisik (pemanasan) dan kimiawi (fungisida sintetik). Kedua cara tersebut dinilai masih kurang efektif karena memiliki beberapa kelemahan. Pengendalian $A$. flavus secara fisik dapat menyebabkan hilangnya zat-zat gizi pada bahan pangan, 
sedangkan penggunaan zat-zat kimia sintetik tidak mudah dan kurang aman dilakukan pada bahan-bahan yang dikonsumsi manusia serta tidak ramah lingkungan.

Upaya pengendalian yang aman dan tidak berbahaya yaitu pengendalian secara hayati. Pengendalian hayati merupakan suatu cara mengurangi jumlah atau menghambat aktivitas metabolisme organisme patogen menggunakan agen hayati. Pendekatan pengendalian hayati yang dapat menjadi alternatif yang efektif, aman dan efisien untuk mengendalikan $A$. flavus adalah pemanfaatan bahan nabati sebagai biofungisida (fungisida nabati). Bahan nabati yang digunakan berupa metabolit sekunder yang terdapat pada ekstrak tumbuhan.

Metabolit sekunder merupakan hasil metabolisme tumbuhan yang tidak digunakan untuk pertumbuhan dan banyak terdapat pada jaringan akar, batang dan daun yang sudah tua. Beberapa jenis metabolit sekunder tumbuhan adalah tanin, flavonoid, terpenoid dan alkaloid. Senyawa tersebut dipercaya dapat menghambat beberapa jenis mikroba dan mempunyai efek samping yang lebih rendah dibandingkan senyawa kimia sintetik ${ }^{6,7}$. Kemampuan metabolit sekunder tumbuhan dalam menghambat pertumbuhan mikroba dengan efek samping yang lebih kecil dibandingkan senyawa kimia sintetik menjadikan metabolit sekunder tumbuhan berpotensi untuk dimanfaatkan sebagai agen pengendali mikroba yang terdapat dalam bahan pangan. Kemampuan metabolit sekunder tumbuhan untuk menghambat pertumbuhan jamur patogen disebut sebagai aktivitas antifungi.

Salah satu tumbuhan yang memiliki beragam metabolit sekunder adalah teh (Camellia sinensis (L.) Kuntze). Pemanfaatan teh sebagai bahan minuman hanya menggunakan pucuk daun teh yang masih muda, sedangkan daun teh yang sudah tua masih belum termanfaatkan secara optimal padahal jaringan daun teh yang tua memiliki kandungan metabolit sekunder yang tinggi. Metabolit sekunder utama yang terdapat pada daun teh berasal dari golongan fenol di antaranya yaitu flavonol, flavonoid dan tanin ${ }^{8}$.
Hasil studi pustaka menunjukkan bahwa dibutuhkan sebanyak $3 \mathrm{mg} / \mathrm{ml}$ ekstrak daun teh untuk menghambat pertumbuhan bakteri Staphylococcus aureus $s^{8}$ Berbeda dengan bakteri, penelitian mengenai pemanfaatan ekstrak daun teh untuk menghambat jamur belum banyak dilakukan, bahkan belum pernah ada laporan mengenai uji penghambatan ekstrak daun teh terhadap pertumbuhan A. flavus. Laporan mengenai pemanfaatan ekstrak daun teh terhadap pertumbuhan jamur, baru dilakukan terhadap Trichophyton mentagrophytes dan $T$. rubrum. Hasil penelitian menunjukkan bahwa konsentrasi ekstrak daun teh yang efektif untuk menghambat kedua jamur tersebut adalah $2,5 \mathrm{mg} / \mathrm{ml}^{9}$.

Berdasarkan latar belakang di atas, penelitian ini bertujuan untuk mengetahui pengaruh ekstrak daun teh terhadap pertumbuhan $A$. Flavus dan konsentrasi ekstrak daun teh yang efektif dalam menghambat pertumbuhan $A$. flavus. Hasil penelitian ini diharapkan dapat memberikan informasi ilmiah tentang aktivitas antifungi ekstrak daun teh terhadap $A$. flavus. Informasi tersebut dapat membantu pemecahan solusi pengendalian $A$. flavus yang efektif dan efisien.

\section{BAHAN DAN METODE}

Ekstraksi daun teh (Modifikasi GramzaMichalowska et al., dan N'guessan et al.) $)^{10,11}$

Tanaman teh yang digunakan dalam penelitian ini adalah tanaman teh varietas assam (Camellia sinensis (L.) Kuntze var assamica) milik Unit Perkebunan PPTK Gambung, Bandung. Daun teh yang digunakan merupakan daun teh yang yang berasal dari tanaman teh yang tua. Tanaman teh yang tua adalah tanaman teh yang sudah berumur lebih dari 5 tahun $^{12}$. Daun teh yang digunakan pada penelitian ini adalah daun teh yang berasal dari tanaman teh berumur 20 tahun.

Daun teh dikeringkan pada suhu kamar selama 7 hari, kemudian daun teh kering dihaluskan dengan blender selama $2 \times 1$ menit hingga menjadi serbuk. Sebanyak $25 \mathrm{~g}$ serbuk daun teh direndam dan dihomogenkan dalam $100 \mathrm{ml}$ etanol 
95\% dengan menggunakan shaker orbital pada suhu ruang selama 24 jam. Larutan disaring menggunakan kertas saring Whatman No.41, kemudian etanol diuapkan menggunakan rotary evaporator. Ekstrak daun teh disimpan pada suhu $4^{\circ} \mathrm{C}$ hingga digunakan.

Penghitungan konsentrasi ekstrak induk yang dihasilkan dilakukan dengan mengambil $1 \mathrm{ml}$ ekstrak kemudian di keringkan menggunakan oven. selanjutnya ekstrak kering ditimbang dan dihitung jumlah berat seluruh ekstrak yang dihasilkan dengan perbandingan pelarut. Setelah diketahui berat ekstrak yang dihasilkan, konsentrasi ekstrak induk dihitung menurut persamaan :

Konsentrasi Ekstrak Induk =

$\frac{\text { Berat ekstrak hasil }(\mathrm{g})}{\text { Berat serbuk awal }(\mathrm{g})} \times 100 \%$

Selanjutnya konsentrasi dikonversi ke dalam bentuk satuan $\mathrm{mg} / \mathrm{ml}$. Setelah diketahui konsentrasi ekstrak induk, dibuat seri konsentrasi perlakuan dengan persamaan untuk pengenceran menurut Parning dan Horale $(2005)^{13}$ sebagai berikut

$\mathrm{M}_{1} \times \mathrm{V}_{1}=\mathrm{M}_{2} \times \mathrm{V}_{2}$

$M_{1}=$ konsentrasi ekstrak induk $(\mathrm{mg} / \mathrm{ml})$

$M_{2}=$ konsentrasi ekstrak yang diinginkan $(\mathrm{mg} / \mathrm{ml})$

$V_{1}=$ volume ekstrak induk $(\mathrm{ml})$

$V_{2}=$ volume ekstrak yang diinginkan $(\mathrm{ml})$

Rendemen ekstrak daun teh dihitung dengan menggunakan persamaan menurut Gramza-Michalowska et al. (2007) sebagai berikut:

$$
\text { Rendemen }=\frac{\mathrm{K}_{1}}{\mathrm{~K}_{0}} \times 100 \%
$$

$K_{0}=$ konsentrasi ekstrak yang diperoleh $(\mathrm{mg} / \mathrm{ml})$

$K_{1}=$ konsentrasi larutan awal $(\mathrm{mg} / \mathrm{ml})$

\section{Uji aktivitas antifungi ekstrak daun teh terhadap A. flavus (Modifikasi Al- Mughrabi et al. $)^{14}$}

Ekstrak daun teh yang telah dibuat dilarutkan dengan akuades steril dengan konsentrasi 0 (kontrol); 0,$5 ; 1,0 ; 1,5 ; 2,0$; 2,$5 ; \quad 3,0$ dan $3,5 \mathrm{mg} / \mathrm{ml}$, kemudian sebanyak $2 \mathrm{ml}$ ekstrak dituang ke dalam cawan petri lalu setelah itu medium PDA sebanyak $10 \mathrm{ml}$ dituangkan dan diratakan dengan ekstrak kemudian dibiarkan memadat. Perlakuan kontrol diberi $2 \mathrm{ml}$ akuades steril. Medium yang sudah padat didiamkan 24 jam agar ekstrak meresap ke dalam medium dan untuk melihat ada tidaknya kontaminasi pada medium. Isolat A. flavus yang telah ditumbuhkan selama 3 hari dipotong menggunakan bor gabus steril dengan diameter $5 \mathrm{~mm}$, kemudian 1 plug inokulum diletakkan dalam cawan petri yang sudah berisi medium dan ekstrak dengan arah miselium menyentuh permukaan medium. Semua perlakuan kemudian diinkubasi pada suhu ruang. Pengamatan aktivitas antifungi ekstrak daun teh dalam menghambat pertumbuhan $A$. flavus dengan cara mengamati diameter koloni $A$. flavus setiap hari. Pengamatan dimulai pada hari pertama setelah inkubasi hingga salah satu isolat tumbuh memenuhi cawan petri. Pengamatan diameter dilakukan dengan menggaris bagian bawah cawan petri menjadi 8 , sehingga pengukuran dilakukan dengan 4 arah berbeda dan diambil rata-ratanya. Persentase penghambatan ekstrak daun teh terhadap pertumbuhan $A$. flavus dihitung dengan persamaan menurut Mori et al. $(1997)^{15}$ sebagai berikut :

$$
\begin{array}{ll} 
& =\frac{K-P}{K} \times 100 \% \\
K & \text { \% penghambatan } \\
P & =\text { Diameter koloni kontrol }(\mathrm{mm}) \\
\text { = Diameter koloni perlakuan }(\mathrm{mm})
\end{array}
$$

\section{Karakterisasi senyawa aktif ekstrak daun teh ${ }^{16}$}

Karakterisasi senyawa-senyawa aktif dari ekstrak daun teh mengacu pada Harborne (1987). Karakterisasi dilakukan dengan Kromatografi Lapis Tipis (KLT) di Laboratorium Kimia Organik Fakultas Sains dan Teknologi Unsoed untuk mengamati adanya senyawa golongan flavonoid, alkaloid, tanin dan terpenoid.

1. Uji flavonoid dengan KLT dilakukan dengan menggunakan fase diam silika gel GF 254, fase gerak asam asetat : $\mathrm{HCl}$ pekat : air (40:3:10) v/v. Bercak yang terelusi dideteksi dengan UV 366 nm dan uap amonia. Adanya flavonoid ditunjukkan oleh terbentuknya bercak yang terlihat 
berwarna secara visual atau perubahan fluoresensi bercak dengan uap amonia.

2. Uji alkaloid dengan KLT dilakukan dengan menggunakan fase diam silika gel GF 245, fase gerak asam asetat : $\mathrm{HCl}$ pekat : air (40:3:10) v/v. Bercak yang terelusi dideteksi dengan UV 254 nm dan $366 \mathrm{~nm}$, serta dengan pereaksi Dragendorff. Adanya alkaloid ditunjukkan oleh terbentuknya bercak berwarna kuning jingga.

3. Uji terpenoid dengan KLT dilakukan dengan menggunakan fase diam silika gel GF 245, fase gerak asam asetat : $\mathrm{HCl}$ pekat : air (40:3:10) v/v. Bercak yang terelusi dideteksi dengan penyemprotan $\mathrm{KMnO}_{4}$ 0,2 \%. Adanya terpenoid ditunjukkan oleh terbentuknya bercak berwarna coklat hitam.

4. Uji Tanin dengan KLT dilakukan dengan menggunakan fase diam silika gel GF 245, fase gerak Etanol : asam asetat : air (14:1:5) v/v. Bercak yang terelusi dideteksi dengan UV 545 - 600 nm. Adanya tanin ditunjukkan oleh terbentuknya bercak yang terlihat berwarna secara visual.

Identifikasi komponen dilakukan dengan kromatografi gas-spektrometri massa (GCMS) di Laboratorium Instrumen Fakultas MIPA UGM, Yogyakarta. Interpretasi spektromassa dilakukan dengan bantuan komputer untuk mencari nilai Linear Retention Indicase (LRI) dari setiap spektra. Selanjutnya spektra tersebut juga dibandingkan dengan pola spektra massa senyawa yang telah diketahui yang terdapat pada data National Institute Standard of Technology (NIST) Library dan Wiley Library atau secara manual dibandingkan dengan literatur.

\section{HASIL DAN PEMBAHASAN}

\section{Karakteristik Ekstrak Etanol Daun Teh}

Ekstrak daun teh yang digunakan pada penelitian ini memiliki rendemen sebesar $12 \%$ dari bahan baku yang digunakan. Hasil ekstraksi tersebut lebih sedikit jika dibandingkan dengan ekstrak daun teh yang dihasilkan GramzaMichalowska et al. (2007) yaitu sebesar $12,2 \%$. Banyaknya jumlah ekstrak yang dihasilkan (rendemen) dipengaruhi oleh beberapa hal di antaranya kehalusan bahan dan lama ekstraksi ${ }^{17}$. Proses menghaluskan bahan pada penelitian Gramza-Michalowska et al. (2007) dilakukan dengan cara maserasi selama 24 jam, sedangkan pada penelitian ini hanya dilakukan dengan blender selama 2 $x 1$ menit. Selain kehalusan bahan dan lama ekstraksi, keberhasilan suatu proses ekstraksi juga dipengaruhi oleh frekuensi pengadukan saat perendaman dan pengeringan bahan ${ }^{18}$.

Hasil uji kromatografi lapis tipis (KLT) menunjukkan bahwa ekstrak etanol daun teh menunjukkan hasil positif terhadap adanya metabolit sekunder golongan flavonoid, tanin, alkaloid dan terpenoid. Selanjutnya senyawa-senyawa volatil dalam ekstrak etanol daun teh diidentifikasi menggunakan kromatografi gas spektrometri massa (GCMS). Berdasarkan hasil uji GCMS ditemukan 19 puncak senyawa aktif dalam ekstrak etanol daun teh, namun hanya diidentifikasi 5 puncak tertinggi (Tabel 1). Kromatogram kelima puncak tertinggi tersebut kemudian dibandingkan dengan data National Institute Standard of Technology (NIST) Library dan Wiley Library. Senyawa-senyawa yang teridentifikasi yaitu caffeine (waktu retensi dan berat molekul: 22.446 dan 194), hexadecanoic acid (waktu retensi dan berat molekul: 23.100 dan 256), neophytadiene (waktu retensi dan berat molekul: 21.675 dan 278), phytol (waktu retensi dan berat molekul: 24.575 dan 296), dan tetracosahexaene (waktu retensi dan berat molekul: 31.792 dan 410). Kelima senyawa tersebut mempunyai karakter sebagai antifungi $^{19,20,21,22,23,24}$. Beberapa hasil penelitian menunjukkan bahwa ekstrak daun teh mengandung fenol, glikosida, saponin, flavonoid, tanin dan catechin ${ }^{25}$. 
Tabel 1.Daftar senyawa Hasil Uji Kromatografi Gas Spektrometri Massa (GCMS) ekstrak etanol daun teh

\begin{tabular}{cllcc}
\hline $\begin{array}{c}\text { Peak } \\
\text { Number }\end{array}$ & Nama Senyawa & Golongan & $\begin{array}{c}\text { Retention Time } \\
(\mathbf{m i n})\end{array}$ & Peak Area (\%) \\
\hline 11 & Kafein & alkaloid & 22,450 & 60,35 \\
\hline 14 & Phytol & terpenoid & 24,575 & 9,14 \\
\hline 12 & Hexadecanoic acid & Asam lemak & 23,100 & 7,54 \\
\hline 18 & Tetracosahexaene & terpenoid & 31,792 & 3,62 \\
\hline 8 & Neophytadiene & terpenoid & 21,675 & 2,34 \\
\hline \multicolumn{2}{c}{ Tidak diidentifikasi } & & & 17,01 \\
\hline Jumlah & & & 100 \\
\hline
\end{tabular}

\section{Aktivitas Ekstrak Etanol Daun Teh terhadap A. flavus}

Hasil pengujian ekstrak daun teh dengan konsentrasi yang berbeda menunjukkan adanya aktivitas antifungi terhadap A. flavus. Hal tersebut dilihat dari terhambatnya pertumbuhan $A$. flavus yang diberi perlakuan ekstrak daun teh. Persentase penghambatan ekstrak daun teh terhadap pertumbuhan $A$. flavus ditentukan dengan pengukuran diameter koloni $A$. flavus selama 8 hari. Rata-rata diameter koloni $A$. flavus selama 8 hari terdapat pada Grafik1.

\section{Grafik 1. Rata-rata diameter pertumbuhan koloni $A$. flavus selama 8 hari}

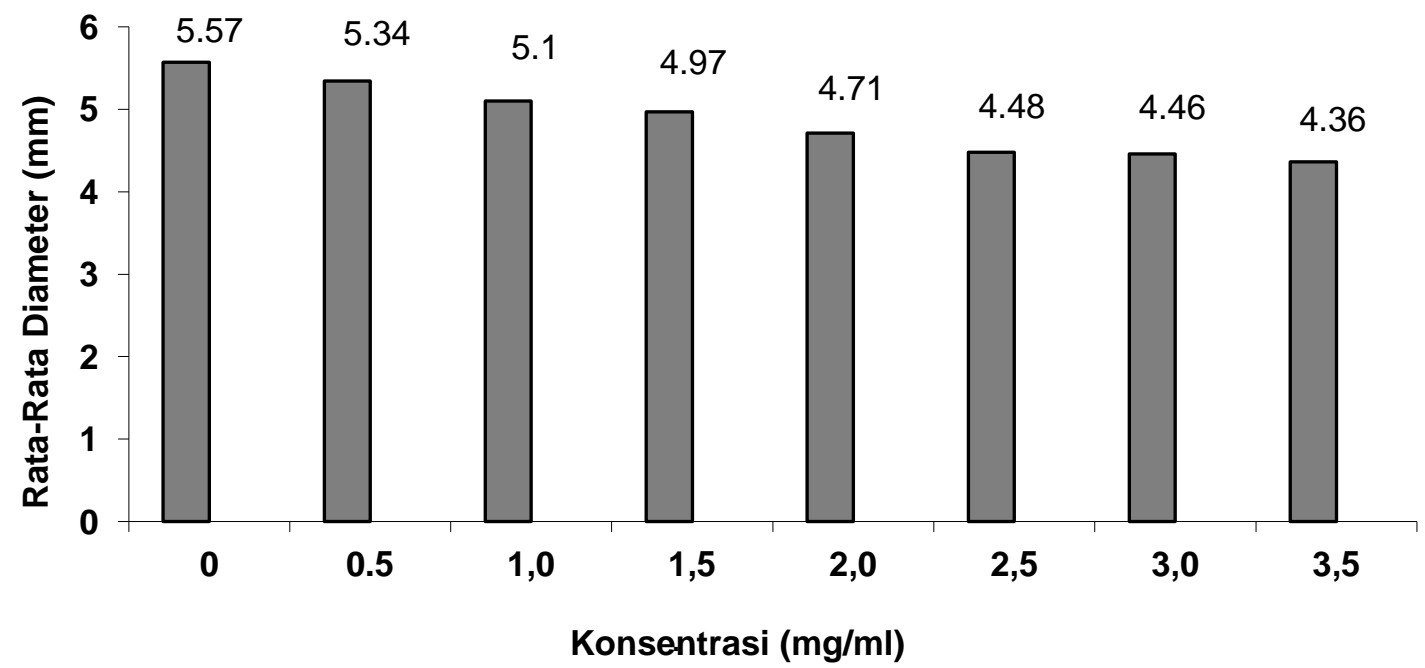

Berdasarkan Grafik 1 dapat dilihat bahwa rata-rata diameter koloni $A$. flavus yang paling tinggi adalah rata-rata pertumbuhan $A$. flavus yang tidak diberi perlakuan ekstrak daun teh (kontrol) dan yang terendah adalah $A$. flavus dengan perlakuan ekstrak daun teh sebanyak 3,5 $\mathrm{mg} / \mathrm{ml}$. Rata-rata diameter koloni $A$. flavussemakin menurun seiring meningkatnya konsentrasi yang diujikan. Selanjutnya data rata-rata pertumbuhan $A$. flavus digunakan untuk menghitung persentase penghambatan ekstrak daun teh terhadap $A$. flavus.

Perbedaan diameter koloni juga menghasilkan persentase penghambatan pertumbuhan $A$. flavus yang berbedabeda. Adanya persentase penghambatan merupakan indikator adanya aktivitas antifungi pada ekstrak daun teh. Persentase penghambatan ekstrak daun teh terhadap $A$. flavus dapat dilihat pada Gambar 2. Berdasarkan Grafik 2 dapat dilihat bahwa persentase penghambatan 
yang dihasilkan oleh perlakuan dengan konsentrasi ekstrak daun teh sebanyak $0,5 \mathrm{mg} / \mathrm{ml}$ merupakan perlakuan dengan persentase penghambatan paling rendah yaitu sebesar 4,42\%. Persentase penghambatan terus meningkat seiring dengan semakin tingginya konsentrasi ekstrak daun teh yang dicobakan. Persentase penghambatan paling tinggi terdapat pada perlakuan konsentrasi ekstrak daun teh sebanyak $3,5 \mathrm{mg} / \mathrm{ml}$ dengan persentase penghambatan sebesar $21,32 \%$.

Grafik 2. Persentase penghambatan ekstrak daun teh terhadap A. flavus

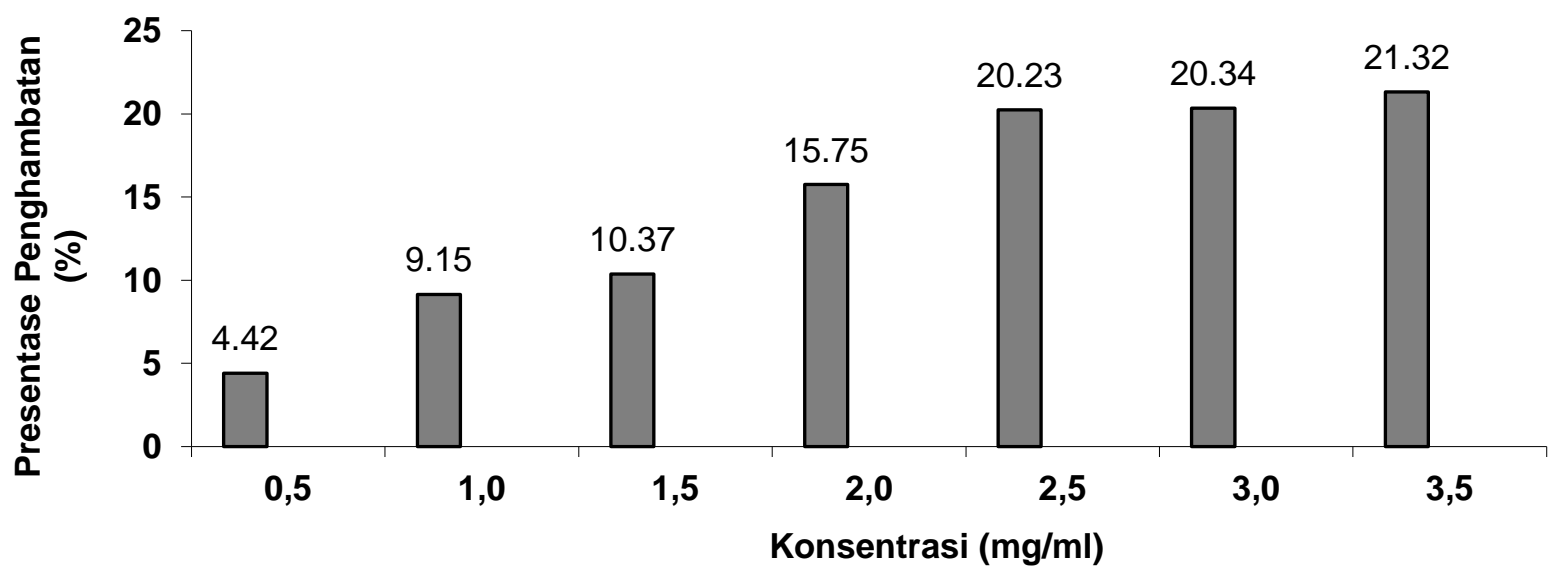

Hasil uji $F$ menunjukkan bahwa perbedaan konsentrasi ekstrak daun teh memberikan pengaruh yang sangat nyata $(p<0,01) \quad$ terhadap persentase penghambatan pertumbuhan $A$. flavus yang dihasilkannya. Pengaruh tersebut perlu diuji lebih lanjut untuk mengetahui konsentrasi yang memberikan pengaruh terbaik. Uji lanjut yang digunakan dalam penelitian ini adalah uji Beda Nyata Jujur (BNJ) pada tingkat kesalahan $5 \%$. Hasil uji BNJpersentase penghambatan ekstrak daun teh terhadap $A$. flavus dapat dilihat pada Tabel 2.

Tabel 2. Hasil Uji BNJ presentase penghambatan ekstrak daun teh terhadap A. Flavus

\begin{tabular}{cc}
\hline $\begin{array}{c}\text { Konsentrasi } \\
\text { Ekstrak Daun } \\
\text { Teh (mg/ml) }\end{array}$ & $\begin{array}{c}\text { Persentase } \\
\text { penghambatan (\%) } \\
\text { SD }\end{array}$ \\
\hline 0(kontrol) & $0,000 \pm 0,000 \mathrm{a}$ \\
0,5 & $4,417 \pm 2,710 \mathrm{ab}$ \\
1,0 & $9,150 \pm 0,961 \mathrm{bc}$ \\
1,5 & $10,370 \pm 1,849 \mathrm{bc}$ \\
2,0 & $15,750 \pm 3,006 \mathrm{~cd}$ \\
2,5 & $20,223 \pm 1,572 \mathrm{~d}$ \\
3,0 & $20,343 \pm 1,106 \mathrm{~d}$ \\
3,5 & $21,323 \pm 4,873 \mathrm{~d}$ \\
\hline
\end{tabular}

Keterangan : huruf yang sama di belakang angka rata-rata pada kolom yang sama menunjukkan perbedaan tidak nyata $(P>0,05)$
Berdasarkan Tabel 2 dapat diketahui bahwa perlakuan yang memberikan pengaruh antifungi paling baik terhadap aktivitas antifungi ekstrak daun teh terhadap $A$. flavus adalah konsentrasi 2,5 - 3,5 mg/ml. Konsentrasi ekstrak yang efektif pada penelitian ini adalah konsentrasi $2,5 \mathrm{mg} / \mathrm{ml}$ karena dapat memberikan hasil yang sama secara statistik dengan konsentrasi $3,5 \mathrm{mg} / \mathrm{ml}$. Berdasarkan tabel klasifikasi aktivitas antifungi Mori et al. $(1997)^{15}$, semua konsentrasi yang dicobakan memiliki aktivitas antifungi yang lemah yaitu dengan penghambatan berkisar antara lebih dari 0 - 25\% (Tabel 3).

Tabel 3. Klasifikasi Aktivitas Antifungi (Mori et al., 1997)

\begin{tabular}{ll}
\hline \multicolumn{1}{c}{$\begin{array}{c}\text { Persentase } \\
\text { Penghambatan (\%) }\end{array}$} & \multicolumn{1}{c}{$\begin{array}{c}\text { Tingkat Aktivitas } \\
\text { Antifungi }\end{array}$} \\
\hline $\mathrm{PP} \geq 75$ & Sangat Kuat \\
$75 \leq \mathrm{PP}<50$ & Kuat \\
$50 \leq \mathrm{PP}<25$ & Sedang \\
$25 \leq \mathrm{PP}<0$ & Lemah \\
0 & Tidak aktif \\
\hline
\end{tabular}


Hasil analisis regresi linier menunjukkan bahwa persentase penghambatan $A$. flavus berkorelasi positif dengan konsentrasi ekstrak daun teh dengan koefisien determinasi $\left(R^{2}\right)$ sebesar $89 \%$. Hubungan antara persentase penghambatan dan konsentrasi ekstrak dapat dirumuskan melalui persamaan:

\section{$Y=1,551+6,369 X$ (persamaan 1)}

keterangan:

$Y=$ persentase penghambatan (\%)

$\mathrm{X}=$ konsentrasi ekstrak $(\mathrm{mg} / \mathrm{ml})$

Berdasarkan persamaan 1 dapat diketahui bahwa konsentrasi ekstrak daun teh memberikan pengaruh positif yang sangat nyata $(p<0,01) \quad$ terhadap persentase penghambatan $A$. flavus. Besarnya pengaruh konsentrasi ekstrak daun teh terhadap persentase penghambatan $A$. flavus adalah $89 \%$. Hubungan antara konsentrasi ekstrak daun teh dengan persentase penghambatan menunjukkan hubungan yang linier dimana peningkatan konsentrasi akan diikuti dengan peningkatan persentase penghambatan (Grafik 3). Setiap peningkatan konsentrasi ekstrak daun teh sebesar $1 \mathrm{mg} / \mathrm{ml}$ mampu meningkatkan persentase penghambatan A. flavus sebesar $6,369 \%$.

Grafik 3. Hubungan regresi antara konsentrasi ekstrak daun teh terhadap persentase penghambatan $A$. flavus

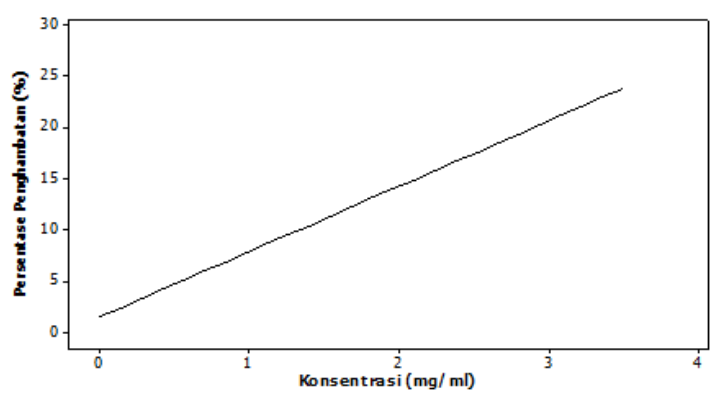

Berdasarkan hasil analisis regresi tersebut, maka peningkatan persentase penghambatan dipengaruhi oleh faktor lain sebesar $11 \%$. Faktor-faktor yang mempengaruhi pertumbuhan $A$. flavus adalah kelembapan, suhu lingkungan dan $\mathrm{pH}$. Hasil pengamatan terhadap suhu ruang pada penelitian ini menunjukkan bahwa suhu ruang berkisar antara 26 $29^{\circ} C^{26}$. Sumartini dan Yusnawan (2005) menyatakan bahwa $A$. flavus tumbuh pada kisaran suhu $10-43^{\circ} \mathrm{C}$ dengan suhu optimum sebesar $32-33^{\circ} \mathrm{C}$, sehingga suhu ruang pada penelitian ini masih memenuhi syarat hidup $A$. flavus namun belum mencapai syarat tumbuh optimal. Selain suhu, $\mathrm{pH}$ awal medium dan $\mathrm{pH}$ akhir medium juga diamati. Hasil pengamatan $\mathrm{pH}$ medium menunjukkan nilai $\mathrm{pH}$ awal yang sama namun didapatkan $\mathrm{pH}$ akhir yang berbeda-beda antar tiap perlakuan. $A$. flavus dapat tumbuh pada $\mathrm{pH}$ 2,73 - 9,9 dengan $\mathrm{pH}$ optimum 6, sehingga $\mathrm{pH}$ medium pertumbuhan $A$. flavus pada penelitian ini masih memenuhi syarat hidup $A$. flavus namun belum mencapai syarat tumbuh optimal ${ }^{27}$. Berdasarkan hasil pengamatan $\mathrm{pH}$, hanya perlakuan kontrol yang mengalami kenaikan $\mathrm{pH}$ sedangkan konsentrasi $0,5-3,5 \mathrm{mg} / \mathrm{ml}$ mengalami penurunan $\mathrm{pH}$ medium. Secara normal, jika pertumbuhan $A$ flavus baik maka medium pertumbuhan $A$. flavus akan mengalami kenaikan $\mathrm{pH}$ seiring bertambahnya pertumbuhan $A$ flavus, namun akan mengalami penurunan $\mathrm{pH}$ medium jika pertumbuhan jamur tidak maksimal $^{27}$.

Adanyapenghambatan pertumbuhan A. flavus oleh ekstrak daun teh menunjukkan adanya aktivitas antifungi dalam ekstrak etanol daun teh. Aktivitas antifungi tersebut disebabkan oleh senyawa antifungi yang dikandungnya. Secara umum, mekanisme kerja senyawa antifungi dalam menghambat pertumbuhan jamur dapat melalui beberapa cara, yaitu menghambat sintesis dinding sel jamur, mengganggu membran sel jamur, menginaktivasi enzim-enzim metabolik dan menghambat sintesis asam nukleat dan protein ${ }^{28}$.

Ekstrak daun teh yang digunakan pada penelitian ini mengandung beberapa metabolit sekunder yang memiliki aktivitas antifungi. Masing-masing metabolit sekunder tersebut memiliki mekanisme aktivitas antifungi yang berbeda-beda. Flavonoid mampu berikatan dengan enzim ekstraseluler dan protein terlarut ${ }^{29}$, selain itu flavonoid juga dapat merusak membran 
sel jamur ${ }^{30}$. Rusaknya membran sel akan mempengaruhi proses pertumbuhan jamur karena membran sel merupakan tempat terjadinya beberapa reaksi enzimatis sel. Tanin mampu menonaktifkan adhesin dan berikatan dengan polisakarida ${ }^{31}$. Selain itu, tanin dapat menghambat enzim dan protein ekstraseluler dan efek langsung terhadap membran ${ }^{32}$.

Mekanisme aktivitas antifungi alkaloid yaitu dengan menyisip di antara dinding sel dan atau DNA kemudian mencegah replikasi DNA jamur sehingga pertumbuhan jamur akan terganggu ${ }^{33,34}$. Salah satu senyawa golongan alkaloid yang ditemukan pada penelitian ini adalah kafein. Kafein dapat mempengaruhi pertumbuhan jamur pada fase awal germinasi, siklus duplikasi nukleus dan pembentukan septum pertama ${ }^{23}$.

Berbeda dengan flavonoid, tanin dan alkaloid, mekanisme penghambatan terpenoid terhadap jamur disebabkan oleh perubahan permeabilitas membran. Gangguan permeabilitas tersebut disebabkan karena terpenoid dapat berperan sebagai pelarut yang mampu memasukkan metabolit sekunder lainnya ke dalam membran ${ }^{35,36}$. Berdasarkan hasil GCMS diidentifikasi 3 senyawa dari golongan terpenoid yaitu phytol, tetracosahexaene dan neophytadiene. Phytol memiliki mekanisme aktivitas antifungi tersendiri yaitu mampu berinteraksi dengan bilayer lipid membran sel sehingga memisahkan bagian membran menjadi dua bagian, yaitu bagian dalam dan bagian luar. Adanya rongga tersebut menyebabkan air dapat masuk kedalam sel sehingga sel akan menggelembung dan pada akhirnya akan terjadi kematian sel atau lisis ${ }^{37}$.

Selain golongan flavonoid, tanin, terpenoid dan alkaloid ditemukan juga golongan asam lemak organik dalam ekstrak daun teh yaitu hexadecanoic acid. Mekanisme penghambatan asam lemak hampir sama dengan mekanisme penghambatan terpenoid. Asam lemak dapat menghambat pertumbuhan dengan cara menyisip di antara membran sel jamur, meningkatkan permeabilitas membran bahkan dapat merusak integritas sitoplasma. Selain itu, asam lemak juga dapat menghambat morfogenesis jamur dan mencegah pembentukan hifa ${ }^{38,39}$.

\section{KESIMPULAN}

Ekstrak daun teh memiliki aktivitas antifungi dan mampu menghambat pertumbuhan $A$. flavus. Konsentrasi ekstrak daun teh yang efektif menghambat pertumbuhan $A$. flavus adalah konsentrasi sebesar $2,5 \mathrm{mg} / \mathrm{ml}$. Kandungan metabolit sekunder daun teh yang berperan sebagai antifungi yaitu golongan alkaloid, flavonoid, terpenoid, tanin dan asam lemak.

\section{DAFTAR PUSTAKA}

1. Huff, W.E., L.F. Kubena, L.B. Harvey, D.E. Corrier, and H.H. Mollenhauer. 1986. Progression aflatoxicosis in broiler chicken. Poultry Science, 65 : 1891-1899.

2. Budiarso, L.T. 1995. Dampak mikotoksin terhadap kesehatan. Cermin Dunia Kedokteran, 103 : 5.

3. Pitt, J.I and Hocking, A.D. 1997. Fungi and Food Spoilage. Blackie Academic \& Professional, London.

4. Purwijantiningsih, E., R.D. Hariyadi., C.C. Nurwitri dan Istiana. 2005. Penghambatan produksi aflatoksin dari Aspergillus flavus oleh kapang dan khamir yang diisolasi dari ragi tempe. Biota, Vol. X (3) : 146-153.

5. Sumartini dan E. Yusnawan. 2005. Upaya menghambat perkembangan Aspergillus flavus pada kacang tanah. Jurnal Litbang Pertanian, 24 (3) : 109112.

6. Wink, M. 1999. Functions of Plant Secondary Metabolites and Their Exploitation in Biotechnology. Sheffield Academic Press Ltd, Sheffield.

7. Cowan, M. M. 1999. Plant Products as Antimicrobial Agents. Clinical Microbiology Review, Vol 12 No. 4 : $564-582$.

8. Hamillton-Miller, J.M.T. 1995. Antimicrobial properties of tea (Camellia sinensis L.). Antimicrobial Agent and Chemotherapy, 39 (11) : 2375-2377. 
9. Okubo, S., M. Toda, Y. Hara and T. Shimamura. 1991. Antifungal and fungicidal activities of tea extract and catechin against Trichophyton. Nippon Saikingaku Zasshi, 46 (2) : 509-14.

10. Gramza-Michalowska, A., J. Korczak and M. Hes. 2007. Purification process influence on green tea extracts' polyphenol content and antioxidant activity. Acta Sci. Pol. Technol. Aliment., 6 (2) : 41-48

11. N'guessan, J.D., M.R. Dinzedi, N. Guessennd, A. Coulibaly, M. Dosso, A.J Djaman and F. Guede-Guina. 2007. Antibacterial activity of the aqueous extract of Thonningia sanguinea against ExtendedSpectrum- $\beta$-Lactamases (ESBL) producing Escherichia coli and Klebsiella pneumoniae strains. Tropical Journal of Pharmaceutical Research, 6 (3) : 779-783.

12. Setyamidjaja, D. 2000. Teh: Budidaya dan Pengolahan. Penerbit Kanisius, Yogyakarta.

13. Parning dan Horale. 2005. Kimia. Yudhistira, Jakarta.

14. Al-Mughrabi, K.I., T.A. Abujai, G.H. Anfoka and W. Shahrour. 2001. Antifungal activity of olivecake extracts. Phytopathologia Mediterrenea, 40 : 240-244.

15. Mori, M., M. Aoyama., S. Doi, A. Kanetoshi dan T. Hayashi. 1997. Antifungal activity of bark extracts of deciduous trees. Holzs als Roh und Werkstoff Spinger-verlag, 55 : 130132.

16. Harborne, J. B. 1987. Metode Fitokimia : Penuntun Cara Modern Menganalisis Tumbuhan. Penerbit ITB. Bandung.

17. Sembiring, B.B., Ma'mun dan E.I. Ginting. Pengaruh kehalusan bahan dan lama ekstraksi terhadap mutu ekstrak temulawak (Curcuma xanthorriza Roxb).Bul. Littro, 17 (2) : 53-58.

18. Suparjana, T.B. 2000. Kajian Toksisitas Beberapa Fraksi Ekstraktif Kayu Sonokembang (Pterocarpus indicus Wild.) dan Nyatoh (Palaquium gutta Baill.) terhadap Rayap Tanah dan Jamur Pelapuk kayu. Thesis. Tidak Dipublikasikan. Program Pascasarjana IPB, Bogor.

19. Goren, A. C., G. Bilsel, M. Altun, F. Satil dan T. Dirmenci. 2003. Fatty acid composition of seeds of Satureja thymbra and $S$. cuneifolia. $Z$. Naturforsch, Vol 58 (22) : 502-504.

20. Tewtrakul, S., S. Yuenyongsawad, S. Kummee dan L. Atsawajaruwan. 2005. Chemical components and biological activities of volatile oil of Kaempferia galanga Linn. J. Sci. Technol., 27(2) : 503-507.

21. Yaili, N., A. Yasar, C. Gulec, A. Usta, S. Kolayli, K. Coskuncelebi dan S. Karaoglu. 2005. Composition and Antimicrobial Activities of essential oils from Centaurea sessilis and Centaurea armena. Phytochemistry, Vol 66 (2005) : 1741-1745.

22. Abad, M. J., M. Ansuategui dan $P$. Bermejo. 2007. Active antifungal substances from natural sources. ARKICOV 2007 (vii) : 116-145.

23. Yuvamoto, P.D., dan Said S. 2007. Germination, duplication cycle and septum formation are altered by caffeine, caffeic acid and cinnamic acid in Aspergillus nidulans. Mikrobiologiia, Vol 76 (6) : 830-833.

24. Saidana, D., M.A. Mahjoub, O. Boussaada, J. Chriaa, I. Cheraif, M. Daami, Z. Mighri dan A.N. Helal. 2008. Chemical composition and antimicrobial activity of volatile compund of Tamarix boveana (Tamaricaceae). Microbiol Res, Vol 163 (4) : 445-455.

25. Paveto, C., M.C. Guida, M.I. Esteva, V. Martino, J. Coussio, M.M. Flawia dan H.N. Torres. 2004. AntiTrypanosoma cruzi Activity of Green Tea (Camellia sinensis) Catechins. Antimicrobial Agents And Chemotherapy, 48 (1) : 69-74.

26. Sumartini dan E. Yusnawan. 2005. Pengaruh jenis dan konsentrasi bahan nabati terhadap perkembangan Aspergillus flavus pada medium PDA dan biji kacang tanah. Majalah IImiah Biologi Biosfera, 22 (1) : 25-29. 
27. Lie, J.L. dan E.H. Marth. 1968. Effect Aflatoxin Formation by Aspergillus flavus and Aspergillus parasiticus in a Casein Substrate at Different $\mathrm{pH}$ Values. J. Dairy Sci., 51 (11) : 1743-1747.

28. Pelczar, J. dan E.C.S. Chan. 1988. Mikrobiologi Dasar Jilid I. UI Press, Jakarta.

29. Al-bayati, F. A. Dan H. F. Al-Mola. 2008. Antibacterial and antifungal activities of different parts of Tribulus terrestris L. growing in Iraq. $J$ Zhejiang Univ Sci B, Vol 9 (2) : 154159.

30. Tsuchiya, H., M. Sato, T. Miyazaki, S. Fujiwara, S. Tanigaki, M. Ohyama, T. Tanaka, I. Takase dan M. Linuma. 1996. Comparative study on the antibacterial activity of phytochemical flavanones against methicillinresistant Staphylococcus aureus. J. Ethnopharmacol, 50 : 27-34.

31. Ya, C., S.H. Gafney, T.H. Lilley dan E. Haslam. 1988. Chemistry and Significance of Condensed Tannins. Plenum Press, New York.

32. Dayang, F. B, S, Razinah dan Paden. 2005. Antimicrobial activities of ethanol and ethyl acetate extracts from the fruits of Solanum torvum. Malays. Appl. Biol., Vol 34(1): 31-36

33. Atta-ur-Rahman, dan M.I. Choudhary. 1995. Diterpenoid and steroidal alkaloids. Nat. Prod. Rep., 12 : 361379.

34. Doughari, J. H. dan J. S. Obidah. 2008. In vitro antifungal activity of stem bark extract of Leptadenia lancifolia. IJIB, Vol 3 (2) : 111-117.

35. Haraguchi, H., S. Kataoka, S. Okamoto, M. Hanafi dan K. Shibata. 1999. Antimicrobial triterpenes from llex integra and the mechanism of antifungal action. Phytotheraphy Research, Vol 13 (2) : 151-156.

36. Gershenzon, J. dan N. Dudareva. 2007. The function of terpene natural products in the natural world. Nature Chemical Biology 5 (3) : 408-414.

37. Chuang, P., C. Lee, J. Chou, M. Murugan, B. Shieh dan H. Chen. 2007. Anti-fungal activity of crude extracts and essential oil of Moringa oleifera Lam. Bioresource Technology, 98 (2007) : 232-236.

38. Tyler, A. dan B. Richard. 2001. Specificity and mode of action of the antifungal fatty acid cis-9heptadecenoic acid produced by Pseudozyma flocculosa. Applied and environmental microbiology, 67 (2) : 956-960.

39. McLain, N., R. Ascanio dan C. Baker. 2000. Undecylenic acid inhibits morphogenesis of Candida albicans. Antimicrob Agents Chemother, Vol 2000 (44) : 2873-2875. 